Araştırma Makalesi - Research Article

\title{
Aile Ödenekleri Programları: Dünya Örnekleri ve Türkiye İçin Bir Model Önerisi ${ }^{1}$
}

\section{Family Allowance Programs: World Examples and Suggestion A Model for Turkey}

\author{
Senol KAYNAKÇ ${ }^{*}$ \\ (iD) 0000-0003-2710-8399
}

\author{
Nagihan DURUSOY ÖZTEPE** \\ (iD) 0000-0001-5963-8592
}

\section{ÖZ}

$\mathrm{Bu}$ çalışmanın temel amacı, seçilmiş refah devleti ülkeleri genelinde, aile ödenekleri programlarının temel özelliklerini ve uygulanış şekillerini ortaya koyarak, Türkiye'de hali hazırda var olan aile ödenekleri uygulamalarının etkinliğini ve eksikliklerini belirlemek ve Türkiye için bir model önerisinde bulunmaktır. Bu amaçtan hareketle çalışmada, 12'si özel, 23'ü kamu çalışanı olmak üzere toplam 35kişi ile derinlemesine görüşme yapılmıştır. Yapılan görüşmelerde kişilere, aile ve çocuk desteklerinin yeterliliği ile bu destekler konusunda nasıl bir uygulama talep ettikleri ve bu uygulamanın finansman kaynağı konusundaki görüşleri sorulmuştur. Elde edilen bulgulara göre Türkiye'de bireylerin önemli bir kısmının aile ödenekleri uygulamalarının genelinden faydalanmadıkları, önemli bir kısmının ise asgari geçim indirimini bir aile ödeneği olarak görmedikleri bulgulanmıştır. Destek taleplerinin büyük ölçüde çocuk bakımı ve eğitim maliyetlerinin karşılanması noktasında yoğunlaştığı; bunun maliyetinin ise büyük ölçüde Devlet tarafindan sağlanan mekanizmalarla finanse edilmesi gerektiği ortaya çıkmıştır. Bu anlamda, Türkiye'de aileye ve çocuklara verilen desteklerin toplumun genelini kapsayan ve çok amaçlı tek bir ödeme çerçevesinde yapılmasının daha işlevsel olacağı düşünülmektedir.

Anahtar Sözcükler: Aile ödenekleri, aile ödenekleri sigortası, aile yardımı, sosyal güvenlik, sosyal sigorta

\begin{abstract}
The main purpose of this study is to determine the effectiveness and shortcomings of family allowances practices in Turkey, and to propose a model for Turkey, by revealing the basic features and application methods of family allowances programs across selected welfare state countries. For this purpose, in-depth interviews were conducted with a total of 35 people, 12 of whom were private and 23 of whom were public employees. In the interviews, people were asked about the adequacy of family and child support, what kind of application they demanded for these supports, and their views on the funding source of this application. According to the findings, it has been found that a significant part of individuals in Turkey do not benefit from family allowances in general, and a significant part of them do not see the minimum living allowance as a family allowance. Support requests are mostly concentrated on meeting the costs of childcare and education; it turned out that the cost of this had to be financed to a large extent by the mechanisms provided by the State. In this sense, it is thought that it would be more functional to support families and children in Turkey within the framework of a single multi-purpose payment that covers the entire society.
\end{abstract}

Keywords: Family allowance, family insurance, family benefits, social security, social insurance

Önerilen atıf șekli: Kaynakçı Ș. ve Durusoy Öztepe, N. (2021). Ayrımcılık Temelli Dışlanma: Aile Ödenekleri Programları: Dünya Örnekleri ve Türkiye İçin Bir Model Önerisi. Sosyal Güvenlik Dergisi (Journal of Social Security). 11(2). 393-413.

- Geliş Tarihi/Received: 20/11/2021 • Güncelleme Tarihi/Revised: 21/12 /2021 • Kabul Tarihi/Accepted: 27/12/2021

1 Çalışma “Aile Ödenekleri Sigortası Kapsamında Dünya Örnekleri Üzerinden Türkiye Modeli Önerisi” adlı yüksek lisans tezinden üretilmiştir.

* $\quad$ Doktora Öğrencisi, Ankara Hacı Bayram Veli Üniversitesi, Lisansüstü Eğitim Enstitüsü, Çalışma Ekonomisi ve Endüstri İlişkileri Anabilim Dalı, senol.kaynakci@hotmail.com

*** Doç. Dr., Pamukkale Üniversitesi, İktisadi İdari Bilimler Fakültesi, Çalışma Ekonomisi ve Endüstri İlişkileri Bölümü, ndurusoy@pau.edu.tr 


\section{GíRiș}

Günümüzde aileye ve çocuklara duyarlı sosyal koruma uygulamalarının önemi giderek artmaktadır. Bu noktada, ailenin hayatını idame ettirme ereği, bireyin hem sosyal hayatını hem çalışma hayatını etkileyecek unsurlardan biri olmakta; buna bağlı olarak da sosyal güvenlik kavramının konusu haline gelmektedir. Ücretin yoksulluğu gideremediği durumda, ailenin yaşamının idame ettirilmesi için bir gelir artışına ihtiyaç duyulduğundan, aile ödenekleri uygulamaları, sosyal politika araçlarından en belirgini olarak gündeme gelmektedir. Aile yönelik ekonomik desteklerin ortaya çıkışı 1890'lı yıllara değin uzanmaktadır. İlk kez bu yıllarda Fransız işçilerin ailelerine işverenlerce "yardım" adı altında ödemeler yapılmaya başlanmıştır. 19. yüzyılda ilk olarak Avrupa'da ortaya çıkan bu uygulamalar 20. yüzyılın başından itibaren farklı ülkeler tarafından da benimsenmiş; hatta bu destekler zamanla pek çok ülkede bir sigorta koluna dönüșmüștür. Aile ödenekleri uygulamalarının $^{2}$ devinimsek olduğunu ve günümüze kadar gelişen süreçte hatırı sayılır bir kurumsallığa eriştiğini söylemek yanlış olmayacaktır.

Aile ödenekleri uygulamaları, aile bireylerinin iyi şartlarda yaşayabilmeleri için yapılan ek gelir transferlerinin genel adıdır. Daha özgül anlamda, aile ödenekleri, aile bireylerinin ulaşım, beslenme, barınma ve eğitimlerine esas hususlarda aile bütçesinde yaşanan gelir kaybının telafi edilmesi amacıyla Devletin ebeveynlere sağladığı gelir transferlerini ifade etmektedir (Gauthier, 2002; Cuyers ve Kiely, 2000). Bu uygulamaların temel amacı, çocuk sahibi ailelerin bakım ve eğitim maliyetlerinin bir kısmını karşılayarak aileye gelir desteği sunmaktır. Aileye ve çocuklara yapılan bu destekler, düzenli nakit ödemelerden eğitimdoğum-sağlık gibi daha spesifik ödemelere kadar çeşitlilik göstermektedir. Hanenin büyüklüğü, çocuk sayısı ve çocukların yaşı, engelli çocuğa sahip olmak, ebeveynlerden birinin ya da ikisinin çalışmaması gibi birçok durum bu desteklerin miktarını, niteliğini ve süresini etkileyebilmektedir. Kimi durumlarda ise desteklerden faydalanmak, çocukların eğitime devam etmesi ya da temel sağlık ihtiyaçlarının karşılanması gibi bir dizi kritere bağlanmaktadır. Ödemeler periyodik olarak yapılmakta, desteğe ihtiyacın kalktığı süre içerisinde de devam edebilmektedir. Periyodik ödemelerin yanısıra, çocuklar için ayni desteklerin yapılması veya iki programın bir arada kullanılması da rastlanan bir durumdur.

Sosyal koruma amacı taşıyan bu desteklerin uygulama biçimleri ülkeden ülkeye farklılık göstermektedir. Aile ödenekleri programları, evrensel programlar, çalışmaya bağlı programlar ve sosyal yardım odaklı programlar olmak üzere üç farklı şekilde uygulanmaktadır. Evrensel model, bireylerin geliri ya da istihdama katılmalarını dikkate almadan vatandaşlık ölçütü ve genellikle ikametgâh koşulu doğrultusunda her bireye sabit nakit faydanın sağlandığı ve finansmanın büyük ölçüde genel bütçeden karşılandığı programlardır. Çalışmaya bağlı modelde ise aile ödenekleri programları ücretli ve maaşlılar

\footnotetext{
${ }^{2}$ Kavramın yabancı literatürde kullanımı "Family Allowances" ya da "Family Benefits" şeklindedir. Türkçe'ye ise "aile ödenekleri” ya da "aile yardımları/aile faydaları" şeklinde çevrilmektedir. Türkiye'de ailelere uygulanan desteklerin tümü (vergi indirimleri, doğum yardımı, kamu personel aile yardımı, şartlı nakit transferler gibi) Devlet tarafından karşılıksız sağlanmakta, şartlı nakit transferler ise "muhtaçlık kriteri” baz alınarak ödenmektedir. Bu anlamda "aile yardımı" kavramının kullanılması daha yaygın olmakla birlikte, "yardım” kavramının genellikle "iyilik yapma, bağış ve muhtaçlık kavramlarıyla daha fazla ilişkilendirilmesi bu desteklerin yalnızca muhtaç ailelere verildiği konusunda bir anlam karmaşasına yol açmaktadır. Kuşkusuz ailenin yoksulluğunu tazmin etmek, aile destek mekanizmalarının amaçlarından yalnızca birini oluşturmaktadır. Çalışmada, anlam karmaşasını önlemek adına aileye yönelik destekler ifade edilirken, Social Security Administration Office (SSA)'ın kullanmış olduğu "Family Allowances" yani aile ödenekleri kavramı kullanılmıștır. Türk Dil Kurumuna göre ödenek kavramı, belirli bir kişiye, kuruluşa ya da topluluğa ayrılmış para olarak tanımlanmakta dolayısıyla yardım kavramından daha kapsayıcı bir anlamda kullanılmaktadır.
} 
ile kimi durumlarda kendi hesabına çalışanlar ve onların bakmakla yükümlü olduğu hane bireyleri için fayda sağlamaktadır. "Aile ödenekleri sigortası" olarak adlandırılan bu programlar, belirli bir istihdam ilişkisi içinde bulunmayı ve edimlerden yararlanmak için prim ödemeyi gerekli kılmaktadır. Sistemin finansmanı, ișçi ve ișveren primleri ile kimi durumlarda devlet sübvansiyonlarından oluşmaktadır. Yardım odaklı modele dâhil programlar ise kapsam bakımından evrensel model ve çalışmaya bağlı model ile farklılıklar barındıran ve genellikle "muhtaçlık" koşuluna bağlı olarak fayda sağlayan programlardır. Bu program kapsamında verilen desteklerden faydalanmanın temel kriteri, bireylerin kendilerini ve ailesini geçindirebilecek düzeyde gelire sahip olamamasıdır. Sistemin finansmanı, tıpkı evrensel modelde olduğu gibi genel bütçeden ya da bunun için özel olarak tahsis edilmiş vergi gelirlerinden karşılanmaktadır.

Avrupa ülkelerinde 20. yüzyılın başında uygulanmaya başlanan gelişmiş aile ödenekleri sigortası Türkiye'de henüz kurulmamıştır. Uluslararası Çalışma Örgütü'nün 102 sayılı Sosyal Güvenliğin Asgari Normları Hakkındaki Sözleşme hükümlerinin bir kısmı 1971 yılında Türkiye tarafından kabul edilmesine rağmen; sözleşmenin aile ödeneklerine ilişkin hükümleri onaylanmamıştır. Herkes için sosyal güvenliğin sağlanmasına yönelik uluslararası taahhütlerin güçlendirilmesi adına ailenin de sosyal koruma kapsamına alınması gerekmektedir. Son yıllarda aile ve evlilik kalıplarının değişmesi, özellikle hane reisi kadın olan tek ebeveynli ailelerin sayısının artması, kadınların artan oranlarda çalışma hayatına girmesi, hane ve çocuk yoksulluğunun artmasıyla birlikte hanenin geçimi ve çocukların bakımı konusundaki talepler de güçlenmiştir. Türkiye'de aileye yönelik desteklerin ise iyileştirilmeye ihtiyacı vardır. Bu uygulamalardan asgari geçim indirimi, kamu personeli aile yardımı, doğum yardımı ve şartlı nakit transferlerine çalışmada yer verilmiştir. Aileye yönelik mevcut desteklerin, hane ihtiyaçlarını tazmin etmekte yeterli olmadığı, çocuk bakımını dikkate almadığı; çocukların korunması ve eğitimin desteklenmesi açısından gelişmeye ihtiyaç duyduğu görülmektedir.

$\mathrm{Bu}$ çalışma, ailedeki gider artışını ya da gelir eksilmesini tazmin etmeyi amaçlayan bu uygulamaları Dünya ve Türkiye örnekleri ile karşılaştırarak analiz etmek ve Türkiye için en işlevsel ve bireylere en fazla faydayı sağlayacak modeli geliştirme çabasını ihtiva etmektedir. Çalışmada öncelikle aile ödenekleri programlarına duyulan ihtiyacın nedenleri açıklanmış ardından farklı ülkelerdeki aile ödenekleri uygulamaları incelenmiştir. Türkiye'de aileye yönelik ekonomik desteklerin yeterliliğini analiz edebilmek adına 12'si özel, 23'ü kamu çalışanı olmak üzere toplam 35 kişi ile derinlemesine görüşme yapılmıştır. Görüşmelerde kişilerin hali hazırda almış oldukları aile ve çocuk desteklerinin yeterliliği ile aile ve çocuk destekleri konusunda nasıl bir uygulama talep ettikleri ve bu uygulamanın finansman kaynağ 1 konusundaki görüşleri açıklığa kavuşturulmaya çalışılmıştır. Çalışmanın son bölümünde ise gerek ülke uygulamalarından gerekse alan araştırması bulgularından elde edilen bilgiler 1şığında Türkiye için bir aile ödenekleri modeli sunulmuştur.

\section{I- AIILE ÖDENEKLERİ PROGRAMLARINA DUYULAN İHTIYACIN NEDENLERİ}

\section{A- Çocuk Yoksulluğu}

UNICEF'e göre (2020) çocuk yoksulluğu hayatta kalmak, gelişmek ve büyümek için ihtiyaç duyulan maddi, manevi ve duygusal kaynaklardan yoksun olmasıdır. Bu tanımda çocuk yoksulluğu, çocukların zihinsel, fiziksel, duygusal ve ruhsal gelişimlerine zarar veren bir durum olarak tanımlanmıştır. Farklı bir ifade ile çocuk yoksulluğu düşük hane geliri veya düşük tüketim seviyeleri gibi geleneksel kavramsallaştırmaların ötesinde özel boyutları olabilen bir durumdur (UNICEF, 2021). Örneğin, maddi yoksunluk yetersiz beslenmeye yol 
açmakta ve bu da sağlık ve eğitimi etkileyerek çocuğun uzun vadeli gelişimine olumsuz yansıyabilmektedir. Ayrıca, mali kaynak eksikliğini gidermek için, yoksul hanelerden çocuklar çocuk işçiliğine dâhil olabilmekte ve bu da çocuğu okuldan mahrum birakarak çocuğun bilişsel ve fiziksel gelişimini olumsuz yönde etkileyebilmektedir (Minujin vd., 2006). Bu noktadan hareketle çocuk yoksulluğunun, çocuğun dışındaki çevresel etmenlerden kaynaklanan ve çocuğu zihinsel ve fiziksel anlamda olumsuz etkileyen çok boyutlu bir süreç olduğu ifade edilebilir (Lichter, 1997: 125).

Hanehalkı yoksulluğu, aile içerisinde yetişkinleri etkilediği gibi çocukları da etkilediğinden, çocuk yoksulluğunun referans noktası olarak kabul edilmektedir. Ebeveynlerin ortalama yaşı, ebeveynlerin eğitimi, hane başına düşen çocuk sayısı ve çocuğun tek ebeveynle yaşayıp yaşamadığı; bununla birlikte ebeveynlerin işgücü piyasasına giriş koşulları ve işsizlik deneyimleri hane ve demografik faktörler üzerinden çocuk yoksulluğunu etkileyen önemli unsurlardır (Chen ve Corak, 2008)

Çocuk yoksulluğunu etkileyen diğer önemli bir unsur Devletlerin gelir transferi programlarıdır. Devlet transferlerinin uygunluk olasılığı ve desteğin miktarı ne kadar yüksekse çocuk yoksulluğu olasılığı da o kadar düşük olmaktadır (Chen ve Corak, 2008). Avrupa Birliği'ne dâhil sekiz ülkede aile sigortası uygulamaları sonrasında hanehalkı yoksulluğu ve çocuk yoksulluğunda önemli derecede azalma meydana geldiği gözlemlenmiştir. Dünya' da çocuk yoksulluğu oranlarına bakıldığında, çocuk yoksulluğunun en düşük olduğu ülkelerin başında Danimarka $(\% 4,7)$, Finlandiya $(\% 3,5)$ ve İzlanda $(\% 5,4)$ gelirken; çocuk yoksulluğunun en fazla olduğu ülkeler Türkiye $(\% 22,7)$, Amerika $(\% 21,2)$ ve Kanada'dır $(\% 11,4)(\mathrm{OECD}, 2020)$. Çocuk yoksulluğunun düşük olduğu ülkelerde evrensel çocuk desteklerinin benimsendiği görülmektedir. Chen ve Corak'ın 2008'de 12 OECD ülkesinde çocuk yoksulluğunu analiz ettiği araştırmanın sonuçlarına göre, Birleşik Krallık'da çocuk yoksulluğundaki düşüşün tamamı hükümet transferlerinden kaynaklanmaktadır. Yine aynı çalışmanın bulgularına göre, Amerika gibi liberal geleneğe sahip ülkelerde, sosyal politikanın tasarımı ile işgücü piyasasının durumu arasında güçlü bir etkileşim varsa, o zaman hükümet transferlerinin yoksulluk oranı üzerindeki etkisinin bir kısmı işgücü piyasası faktörleri ile iç içe geçmekte; ebeveyn istihdamının artışıyla birlikte çocuk yoksulluğu azalmaktadır (Chen ve Corak, 2008).

\section{B- Tek Ebeveynli Ailelerin Sayısının Artması}

Toplumun süreğen yapısı değişimlere yol açmaktadır. Bu durum ise ister istemez toplumun en temel birimi olan ailenin de değişimini beraberinde getirmekte ve tek ebeveynli ailelerin sayısı gün geçtikçe artmaktadır (Demir ve Genç Çelebi, 2017). Tek ebeveynli aile, boşanma, ölüm, evlat edinme, ebeveynlerden birisinin çalışma koşulları sebebiyle uzun süre aile ile bulunamaması gibi nedenlerle çocuğun yalnızca annesi ya da yalnızca babası ile yaşama durumudur (Aslantürk ve Koç, 2019). Tek ebeveynli aile haline gelme, çocuk için ve çocukla beraber kalan ebeveyn için durumu çocuk bakımı ve korunması açısından zor hale getirmektedir. Feyzioğlu ve Kuşçuoğlu'nun (2011: 101) çalışmasına göre, anne ile çocuğun oluşturduğu tek ebeveynli ailelerde ekonomik problemler daha ön planda olmakta, ev geçindirmede kira ve fatura ödemelerinde zorlanılmakta ve okul masraflarının karşılanmasında zorluk çekilmektedir. Baba ile yaşayan çocuğun oluşturduğu tek ebeveynli ailede isebahsedilen ekonomik problemlerin daha az ön planda olduğu, fakat yeme içme gibi temel ihtiyaçlar için daha çok harcama yapıldığı görülmektedir. Her iki durumda da çocuğa yapılacak olan sosyal harcamalarda zorlanıldığından bahsedilmektedir. Bu durum hem hane hem de çocuk yoksulluğu ile mücadelede aileye yapılacak desteklerin önemini bir kez daha ortaya koymaktadır. 


\section{C- Kadınların Artan Oranda Çalıșma Yașamına Girmesi}

2007 y1lından günümüze kadar çoğu ülkede ve özellikle Türkiye'de kadınların işgücüne katılım oranı her yıl artış göstermektedir. Öyle ki şu an gelinen noktada Türkiye, niceliksel olarak kadın istihdamının artış gösterdiği Dünya'da üçüncü ülke olarak gösterilmektedir. Bu durumun nedenleri arasında,kentleşme hızının yüksek oluşu, okullaşma oranının artması ve tüketim harcamalarındaki artış bulunmaktadır (Karadeniz ve Yılmaz, 2018: 50). Hane gelirini arttırmak için işgücüne katılan kadının, sosyal risk kapsamında bulunan analık ile çocuk bakımı ya da sağlık sebepli olmak üzere belirli bir süre istihdam dışı kalması gelir kaybına uğraması anlamına gelmektedir (Daly ve Clavero,2002: 124). Gelir kaybına uğrayan hane halkının desteklemek gerekliliği kaçınılmazdır. Bu desteğin aile sigortası kapsamında ve nakdi olarak gerçekleşmesi ise elzemdir (Bradshaw ve Finch, 2002: 178). Aksi takdirde analık sigortası kapsamındaki ebeveyn izinleri kadının işgücüne katılımını arttırma amacına sahip olmadığı gibi kadını çalışma yaşamının dışına çıkarmaktadır. Bunun yanı sıra gelir telafi edici ödemeler ile sabit miktar ödemeler arasındaki kritik fark kadının istihdamını önemli ölçüde etkilemektedir (Daly ve Clavero, 2002: 124). Her iki ebeveynin istihdama katılması sonucu, çocuğun bakımını üstlenecek aile ferdinin bulunmayışı, ebeveynlerden birinin istihdam dışında kalmaması için çocuk bakımı ve kreş uygulamalarına yönelik bir aile ödenekleri programı ihtiyacını arttırmaktadır. Annelik izni ve ücretsiz izinler, kadınları istihdam alanı dışına çıkarma riski barındırdığından, nakdi ödeme şeklinde yapılan aile ödeneklerinin kadınları istihdam içinde tutma olasılığı yüksek görünmektedir (Ünlütürk Ulutaş, 2015). Kadınların artan oranda işgücü piyasasına girmesi çocuk yoksulluğunun azaltılması açısından da önemli bir işleve sahiptir. Chen ve Corak'ın 2008'de yaptığ 1 çalışmanın bulgularına göre, annelerin artan işgücü piyasası katılımı, sürekli olarak daha düşük çocuk yoksulluğu oranlarını ortaya çıkarırken; tam tersi şekilde anne babaların istihdam oranlarındaki ve kazançlarındaki düşüşler, daha yüksek çocuk yoksulluğu oranlarına neden olmuştur.

\section{II- FARKLI REFAH DEVLETİ ÜLKELERINDE AİLE ÖDENEKLERİ PROGRAMLARI ${ }^{3}$}

\section{A- Almanya}

Almanya'da aileye yönelik destekler, çocuk yardımları, ebeveyn destekleri, analık yardımları, vergi indirimleri ve bakım avansı şeklinde oldukça geniş bir uygulama kapsamında yürütülmektedir. Çocuk yardımı uygulaması, çocuk çalışmıyor olduğu sürece 18 yaşına kadar tüm çocukları kapsamaktadır. Ancak 18-21 yaş arasındaki çocuklar Almanya'da "işsiz" olarak başvuruda bulunduysa ve bu süre zarfında herhangi bir kurumdan işsizlik yardımı almıyor ise bu destekler 21 yaşına kadar uzatılmaktadır. Bununla birlikte, mesleki eğitim veren okullarda okuyan, iş yerinde mesleki eğitim ve geliştirici meslek eğitimleri alan çocuklar için ise en fazla 25 yaşına kadar çocuk yardımı yapılabilmektedir (BMAS, 2018: 8). $\mathrm{Bu}$ anlamda Almanya'da çocuk yardımı uygulaması yukarıdaki koşullar sağlandığı takdirde çocuklar evli olmamak kaydıyla 25 yaşına kadar yapılabilmektedir. 2021 yılı için Almanya'da çocuk parası miktarı birinci ve ikinci çocuk için ayda 219 Euro, üçüncü çocuk için 225 Euro, dördüncü ve sonraki her bir çocuk için ayda 250 Euro'dur (Berlin, 2021). Almanya'da çocuk parası için başvuruda bulunan ailenin bu hakkı elde edebilmesi için

\footnotetext{
${ }^{3}$ Çalışma kapsamında incelenen ülkeler, Refah Devleti sınıflandırmalarında halen yaygın olarak başvurulan EspingAndersen'in refah devleti sınıflandırmasına göre seçilmiştir. Esping-Andersen'in refah rejimi sınıflaması üç farklı modele dayanmaktadır. Bunlar, Liberal Refah Devleti (ABD, İngiltere), Kita Avrupası Refah Devleti (Fransa, Almanya, Belçika) ve Sosyal Demokrat Refah Devleti (İsveç, Danimarka). Ayrıntılı bilgi için bkz: EspingAndersen, G. (1996) Three Worlds of Welfare Capitalism, Cambridge, UK: Polity. Press.
} 
ikamet iznine sahip olması gerekmektedir; bununla birlikte çocukların da aile ile yaşaması zorunludur. Belirli ön koşullar altında, başka bir $\mathrm{AB}$ ülkesinde veya Almanya Federal Cumhuriyeti'nin sosyal güvenlik konusunda anlaşma yaptığ yaşamakta olan çocuklar için de çocuk yardımı başvurusunda bulunmak mümkündür(Berlin, 2021). Böyle bir durumda çocuk yardımının miktarı, çocuğun Almanya'da yaşaması durumuna göre daha düşüktür. Almanya'da çocuk parası uygulamasında hanelerin gelir durumuna bakılmamakta; en az bir çocuğu olan ebeveynler, torunları ile yaşayan büyükanne ve büyükbabalar, vesayetinde en az bir çocuk bulunan vasiler ile yetim ve öksüz çocuklar da çocuk parası uygulamasından faydalanabilmektedir. Ayrıca düşük gelirli aileler için çocuk parasına ek olarak gelir testine bağlı "çocuk yardımı" uygulaması da bulunmaktadır. Bu anlamda Almanya'da çocuklara sağlanan ödemeler çocuk parası ve çocuk yardımı şeklinde hem evrensel model hem de sosyal yardım modeli çerçevesinde gerçekleştirilmektedir.

Almanya'da aile yardımı uygulamalarından bir diğeri ise "Ebeveyn parası" uygulamasıdır. Uygulamanın amacı çocuğun doğumu itibariyle ebeveynlerin bakım için işgücü piyasasının dışına çıkmasıyla birlikte yoksun kalınan gelirin telafisini sağlamaktır. Doğumdan sonra çocuğuna kendisi bakan ve çalışmaya ara veren veya haftada 30 saatten az çalışan tüm anne ve babalar ebeveyn parası almaya hak kazanmaktadır. Bununla birlikte, kursiyerler ve öğrenciler, ev kadınları ile daha büyük çocuklarına bakmak için çalışmayan ebeveynler de ebeveyn parası alma hakkına sahiptir (Berlin, 2021). Almanya'da ebeveyn parası uygulaması üç şekilde uygulanmaktadır. Bunlar; temel ebeveyn parası, artı ebeveyn parası ve ortaklık ikramiyesi uygulamasıdır. Temel ebeveyn parası uygulaması çocuğun doğumundan itibaren en az 2 en fazla 14 ay süreyle ödenmektedir. Her iki ebeveyn de bu ödenekten faydalanıyorsa öngörülen süre her ikisi arasında, tercih ettikleri şekilde, paylaştırılmaktadır. Bekâr ebeveynler 14 aylık süreye ek olarak 2 ay daha fazla bu ödenekten yararlanabilmektedir (Familien Portal, 2021). Yapılacak ödemenin miktarı, başvuran veya bakmakla yükümlü olan ebeveynin, çocuk doğmadan önceki ortalama aylık net gelirine göre belirlenmektedir. Aylık ortalama geliri 1.000 ile 1.200 Euro arasında olan ebeveynlere, doğumdan sonra bağlanacak ödenek miktarı aylık ortalama gelirinin \%67'si iken aylık ortalama geliri 1.200 Euro ve daha fazla olan ebeveynlere bağlanacak ödenek miktarı doğumdan önceki aylık ortalama kazancın \%65'ine düşmektedir. Doğumdan önceki aylık geliri 1.000 Euro'dan daha az olan ebeveynlere ise bağlanacak aylık miktarı kademeli olarak \%100'e kadar çıkabilmektedir (Familien Portal, 2021). Bu şekilde hesaplanan ödeneklerin miktarı en az 300 Euro, en fazla 1.800 Euro'dur.

Artı ebeveyn parası uygulaması ise işe daha erken dönmek isteyen ebeveynlere yöneliktir. Bu uygulama, yarı zamanlı çalışma ile ebeveyn parasını birleştirme imkânı sunmaktadır. Bu anlamda iş ve aile yaşamı uyumunu güçlendirmesi anlamında önemli bir uygulamadır. Doğumdan hemen sonra yarı zamanlı çalışmaya başlayan ebeveynler ücretlerine ek olarak art1 ebeveyn parasından faydalanabilmektedir (BMFSFJ, 2021). Bu uygulamadan faydalanma süresi 2 yıldır. Bu anlamda temel ebeveyn parası uygulamasından daha uzun sürelidir. Ebeveynler, temel ebeveyn parası uygulaması ile art1 ebeveyn parası uygulamasından yalnızca birini tercih edebilecekleri gibi, her ikisini de birleştirerek kullanabilirler. Ortaklık ikramiyesi ise, her iki ebeveynin arka arkaya dört ay boyunca haftada 25 ila 30 saat arasında yarı zamanlı çalışması durumunda ek olarak dört ay daha artı ebeveyn parası almaya hak kazanması durumudur (BMFSFJ, 2021). Başka bir ifade ile ortaklık ikramiyesi her iki ebeveynin de yarı zamanlı çalışması durumunda artı ebeveyn parasını daha uzun süre alması anlamına gelmektedir. Almanya'da ebeveyn ödemeleri çocuk sayısına ve çoklu doğum durumlarına göre artan oranlarda uygulanabilmekte; ayrıca yapılan tüm ödemeler yalnızca doğum yoluyla değil aynı zamanda evlat edinme uygulamasında da geçerli olabilmektedir (BMFSFJ, 2021). 


\section{B- Fransa}

Fransa'da aile ödenekleri uygulamaları, 20 yaşın altında bir veya daha fazla çocuğu bulunan Fransız ve yabancı uyruklu bireylere gelir durumları baz alınarak verilen mali yardımları ifade etmektedir (CLEISS, 2021). Evlat edinilen çocukları da kapsayan bu yardımlar, yalnızca ebeveynlere değil aynı zamanda çocuğun sürekli bakımını üstlenen diğer kişilere verilmektedir. Bununla birlikte, 20 yaş altında olup çalışan ancak elde ettiği geliri net asgari ücretin \%78'sini aşmayan tüm çocuklar için de bu yardımlardan yararlanılmaktadır. Aile yardımı uygulamaları, Fransa'da çocuklarıyla birlikte ikamet eden, ücretliler, ücretlilere benzer diğer tüm mesleklerde çalışanlar, tarım dışı sektörlerde kendi hesabına çalışanlar ile herhangi bir meslekte faaliyet göstermeyen tüm aileleri kapsamaktadır (CLEISS, 2021). Bu anlamda Fransa aile yardımı uygulamaları yararlanıcılar açısından evrensel modelin izlerini taşımaktadır. Sistemin finansman kaynağı ise işveren ve kendi hesabına çalışanların sunduğu katkıların yanı sıra devletin istihdama katılmayanlar ya da katılamayanlar için yaptığı katkılardan oluşmaktadır (ISSA, 2018: 128).

Fransa'da aileye yapılan destekler genel bakım destekleri, erken çocukluk dönemi destekleri ve aileye yönelik özel amaçlı destekler olmak üzere üç farklı şekilde uygulanmaktadır. Genel bakım destekleri aile yardımı, götürü ödenek, aile takviyesi ve aile yardımı ödeneği olmak üzere dörde ayrılmaktadır. Aile yardımı, Fransa'da ikamet etmek koşuluyla 20 yaşından küçük iki veya daha fazla bağımlı çocuğa sahip ailelere yapılan ödemelerdir. Bu ödemelerin miktarı ailenin gelir durumu ve çocuk sayısına bağlı olarak değişebilmektedir (ISSA, 2018). Bununla birlikte en az 3 bağımlı çocuğu bulunan ailelerde, eğer çocuklarından biri 20 yaşına, başka bir ifade ile aile yardımı ödemesi için üst yaş sınırına ulaşmışsa ve hala ailesinin yanında yaşıyor ise bu ailelere yararlanamadıkları aile yardımının bir kısmı sabit oranlı ödenek şeklinde verilir. Götürü ödenek şeklinde tanımlanan bu uygulama, çocuğun 20. yaş gününe ulaştığı ayın birinci gününden 21. yaş gününden önceki aya kadar bir yıl süreyle ödenmektedir (CLEISS, 2021). Aile takviyesi uygulaması ise 3 yaşından büyük, 21 yaşından küçük en az 3 bağımlı çocuğu olan ailelere gelir testine bağlı olarak yapılan ödemeleri ifade etmektedir. Bu ödemeyi elde ekmek için ailenin toplam yıllık gelirinin, çocuk sayısı ve aile durumuna göre değişen bir üst sınırı aşmaması gerekmektedir (CLEISS, 2021). Bununla birlikte, çocuğun anne ya da babası ya da her ikisinin birden olmaması durumunda aile desteği ödeneği verilmektedir. Çocuğa bakan tek ebeveyn olması durumunda ödenek miktarı $116,69 €$ iken hem annesi hem de babasının olmaması durumunda verilen ödenek miktarı $155,55 €$ 'ya yükselmektedir.

Fransa'da erken çocukluk dönemi ödemeleri ise dört başlık altında uygulanmaktadır. Bunlardan ilki doğumdan iki ay sonra her çocuk için yapılan "doğum ve evlat edinme ikramiyesi” (ISSA, 2018). Bu ödemeler ile çocuğun doğumuyla veya evlat edinilmesi ile bağlantılı masrafların karşılanması amaçlanır. Her iki ödenekte de ailenin belirli bir gelir seviyesini aşmaması gerekmektedir. Ödeneklerin verilmesi için şart koşulan gelir seviyesi tavanları ailenin çift gelirli ya da tek gelirli olup olmaması veyahut çocuk sayısına göre farklı sınırlarda gerçekleşebilmektedir. 2021 yılı için ödenen doğum ikramiyesi tutarı her doğum için 953,03 €; 20 yaşından küçük bir çocuğun evlat edinilmesi durumunda ise evlat edinme ikramiyesi miktarı 1.906,05 €'dur (CLEISS, 2021). Doğum ve bebek bakımı için yapılan desteklerden bir diğeri ise "temel ödenek" olarak adlandırılmaktadır. Temel ödenek, çocuğun bakım ve eğitimi ile ilgili masrafların karşılanması amacıyla çocuk 3 yaşına gelene kadar yapılan aylık ödemelerdir. Evlat edinme durumunda ise 20 yaşından küçük bir çocuğun eve gelişinden itibaren 3 yıl süreyle temel ödenek verilmektedir. Tıpkı doğum ikramiyesinde olduğu gibi bu ödenek de gelir testi koşullarına göre belirli bir gelir seviyesinin altında kalan ailelere sağlanmaktadır (Service-public.fr, 2021a). Erken çocukluk dönemi bakım yardımlarından bir diğeri ise "ortak çocuk yetiştirme parası" uygulamasıdır. 3 yaşından 
küçük (veya evlat edinme durumunda 20 yaşından küçük) en az bir çocuğu bulunan ebeveynler, eğer çocukların bakımını kendileri yapıyor ise ve bu nedenle çalışma yaşamından kısmen ya da tamamen ayrılmışlar ise böyle bir yardımı almaya hak kazanmaktadırlar. $\mathrm{Bu}$ ödemeden faydalanabilmek için ebeveynin mesleki faaliyetine tamamen veya kısmen ara vermesi ve yaşlılık sigortası katkı paylarının en az dörtte birini ödemiş olması gerekmektedir (Service-public.fr, 2021a). Diğerlerinden farklı olarak gelir testine bağlı olmadan yapılan bu ödemelerin miktarı ebeveynin çalışma aktivitesini azaltma ölçüsüne göre farklılık göstermektedir. 2021 yılı için çalışmaya tamamen ara veren ebeveynlere ödenen ödenek miktarı aylık 400,79 € iken, çalışma süresi \%50 ve daha az olduğu durumlarda $259,09 €$, çalışma süresi $\% 50$ ile $\% 80$ oranında olduğunda ise aylık 149,46€ tutarında ödeme yapılmaktadır. Çalışmayı tamamen bırakan ve en az 3 çocuğu bulunan ebeveyne ise ortak çocuk yetiştirme parası daha yüksek ödenmektedir. Bu kapsamda ödenen miktar 2021 yılı için 655,11 €'dur (CLEISS, 2021). Ortak çocuk eğitimi yardımı birinci çocuk için 6 ay, ikinci çocuk için 24 ay, üçüncü ve daha fazla çocuk için 48 ay boyunca verilmektedir. Ancak ebeveynlerin her ikisinin de çalışması durumunda, 6 yaşından küçük çocukların evde ya da kreşteki bakım maliyetlerini karşılamak amacıyla "çocuk bakım parası” ödenmektedir. Çocuk bakımı eğitimli bir bakıcı, ev hizmetlerinde çalışan bir kişi ya da bir kreş tarafından sağlanabilir. Böyle bir durumda çocuk bakım maliyetinin en fazla \%85'ine kadar olan kısmı aile ödeneği fonundan karşılanabilmektedir. Ebeveynler bakıcı ücretinin en az \%15'ini ödeme yükümlülüğündedir. Karşılanan oran çocuk sayısına, çocukların yaşlarına ve ailenin gelirine bağlı olarak değişmektedir. Hatta çocuğun bakımını tek başına üstlenen tek ebeveynli ailelerde çocuk bakım desteği \%40 oranında artırılmaktadır(CLEISS, 2021). Aile ödenekleri fonu ayrıca, eğitimli bir bakıcı için sosyal güvenlik katkı paylarının tamamını; evde çocuk bakım hizmeti sağlayıcısı için ise sosyal güvenlik katkı paylarının \%50'sini geri ödemektedir. Yarı zamanlı çalışan ebeveynlerde çocuk bakım parası azaltılmış şekilde ödenmektedir.

Fransa'da aile ödenekleri fonundan, çocukların ve yetişkinlerin engellilik durumlarına, çocuğun ciddi bir hastalık ya da engelinin olmasına, çocuğun ölümüne, ailenin barınma ve taşınma ihtiyaçlarına göre farklılaşan özel amaçlı yardımlar da yapılmaktadır (CLEISS, 2021; ISSA, 2018: 128).

\section{C- Kanada}

Kanada'da aileye yönelik maddi destekler yardım odaklı model çerçevesinde şekillenmiştir ve yardım ödemeleri gelir testine bağlı olarak yapılmaktadır. Genel anlamda aile yardımı uygulaması üç yöntemle gerçekleşmektedir. Bunlardan ikisi mal/hizmetler vergisi ve bölge bazlı ödemelerden oluşmaktadır. Diğer ödeme programı ise Kanada Çocuk Parası olarak adlandırılmaktadır. Kanada çocuk parası uygulaması, 18 yaşından küçük çocukların yetiştirme masraflarına yardımcı olmak amacıyla çocuğun bakımından ve yetiştirilmesinden birinci derecede sorumlu olan kişilere ödenmektedir (Goverment of Canada, 2021a). Ödenecek tutar çocuk sayısına, çocukların yaşlarına, hanenin yıllık net gelirine ve çocuğun engellilik durumuna göre değişebilmektedir. Kanada Çocuk Yardımı vergi sistemi aracılığıyla yönetildiğinden, çocuğun bakımından birincil sorumlu kişinin yardımı alabilmek için y1llık gelir vergisi beyannamesi vermesi gerekmektedir (ISSA, 2019). Hanenin yıllık ortalama net geliri 32.028 Kanada dolarının altında olduğu durumlarda 6 yaşın altındaki her çocuk için yılda 6.833 Kanada Doları (ayda 569,41 Kanada Doları); 6 ila 17 yaş arasındaki her çocuk için ise yılda 5,765 Kanada Doları (ayda 480,41 Kanada Doları) ödeme yapılmaktadır (Goverment of Canada, 2021a). Belirtilen ödemeler hanehalkı geliri arttıkça kademeli olarak düşmektedir. Ödemelerin finansman kaynağı ise gelir vergisi sistemidir (ISSA, 2019: 95). Kanada çocuk parası uygulamasından faydalanmada, ebeveynlerin gelirlerinde değişim olsun ya da olmasın her yıl müracaatları aranmaktadır. Bu ödemelerin 
yanı sıra, 18 yaşından küçük ve uzun süreli fiziksel, zihinsel ve ruhsal engelli çocuğu olan ailelere ek ödenek sağlanmaktadır. Engelli çocuk ödeneği adı verilen bu uygulama yine hanenin y1llık net gelirine göre farklılaşmaktadır. Hanenin yıllık ortalama net geliri 69.395 Kanada Doları ve altında olduğu durumlarda her bir engelli çocuk için ödenen tutar aylık 242,91 dolar; yıllık ise toplamda 2,915 Kanada dolarıdır ve bu ödemeler tamamen vergiden muaf tutulmaktadır (Goverment of Canada, 2021b).

\section{D- Amerika Birleşik Devletleri}

Amerika Birleşik Devletleri'nde Almanya ve Fransa'ya benzer aile sigortası modellerinden bahsetmek mümkün değildir. Yardım odaklı model içerisinde değerlendirilebilecek uygulamalara sahip Amerika Birleșik Devletleri'nde gelir testiyoluyla fayda sağlayan seksen civarında program mevcuttur (ISSA, 2019: 241). Amerika Birleşik Devletleri'nde aile yardımı uygulamaları ve politikalarının gelişmemesinin en büyük nedeni devletin bu gibi refah hizmetlerini piyasaya ve aileye devretmesidir. Çocuk bakımı ve yardımı tamamen piyasa ile aile arasında halledilmesi gereken bir mesele olarak görülmekte, kamu kaynakları aile politikalarına önem vermemektedir (Lewin, 1999: 4). Ülkede aileye yönelik kısıtlı uygulamalar muhtaçlık/yoksulluk koşuluna göre gerçekleşmektedir. Gelir testi yoluyla verilen bu yardımlar doğrudan bir nakdi destekten ziyade vergi iadeleri ya da vergi indirimleri şeklinde gerçekleşmekte ve nüfusun çok az bir kesimi bu yardımlardan faydalanmaktadır (Henneck, 2003: 8). Vergi iadeleri yoluyla yapılan yardımlar medeni duruma ve çocuk sayısına göre değişmektedir. 2019 yılı için vergi iadesi yoluyla sağlanan aile yardımı, yıllık geliri 15.820 doların altında çocuksuz bekâr bir bireye ve yıllık geliri 21.710 Dolar'ın altında evli bireylere/ailelere yıllık 538 Dolar'a kadar yapılabilmektedir. Yine aynı yıl için en az üç çocuğu bulunan ailelerden tek ebeveynli olanların yıllık geliri 50.594 doların altında, çift ebeveynli olanların yıllık geliri 56.844 Dolar'ın altında olanlara yıllık 6.660 Dolar'a kadar aile ve çocuk yardımı yapılabilmektedir (ISSA, 2019:241).

Amerika'da çeşitli isimlerde ve dolaylı olarak ailenin refahı için uygulanan farklı aile yardımları da bulunmaktadır. Bu yardımlardan biri "gıda desteği programıdır". Yoksul ailelerin gıdaya yönelik harcama yapmaları için satın alma gücünü arttırma amaçlı programdır. Yetersiz beslenmeyi bitirme amacı da taşımaktadır. Bu kapsamda var olan uygulamalardan bazılarına "kadınlar, reşit olmayanlar ve çocuklara yönelik tamamlayıcı gıda yardımı”, “okul kahvaltı ve öğle yemeği programı”, “çocuk ve yetişkin gıda yardımı” örnek verilebilir.

\section{E- İsveç}

İsveç, aile sigortası konusunda evrensel modele örnek gösterilecek uygulamalara sahiptir. Aile sigortasından faydalanmanın en önemli koşulu İsveç’te ikamet ediyor olmaktır. İkamet şartı yalnızca ebeveyn için değil, çocuk için de geçerlidir. İsveç'te ikamet eden tüm bireyleri kapsayan bu uygulamaların finansman kaynağı ise devlettir (ISSA, 2018: 355).

İsveç'in aile yardımı uygulamalarından en belirgini çocuk yardımıdır. Çocuk yardımı, İsveç'te ikamet ediyor olmak koşuluyla, hanenin gelir düzeyine bakılmaksızın ebeveynlere yapılan ödemeleri kapsamaktadır. Her çocuk için ödenen miktar ebeveynler arasında paylaştırılmakta; eğer tek ebeveyn var ise ödeme toplam olarak o ebeveyne yapılmaktadır. Ödeme 16 yaşına kadar olan tüm çocukları kapsamaktadır (Försäkringskassen, 2021). Doğum yoluyla sahip olunan çocuklar için doğumun ertesi ayından itibaren, evlat edinilen çocuklar için ise evlat edindikten bir ay sonra ödeme başlamaktadır. İsveç'te çocuk parası 2021 yılında her bir çocuk için 1.250 İsveç Kronudur(Försäkringskassen, 2021). Bu miktara ek olarak, ikinci çocuk için aylık 150 İsveç Kronu, üçüncü çocuk için aylık 730 İsveç Kronu, dördüncü çocuk için aylık 1.740 İsveç Kronu, beşinci çocuk için aylık 2.990 İsveç Kronu, 
altıncı ve daha fazla çocuk için aylık 4.240 İsveç Kronu ödeme yapılmaktadır (Försäkringskassen, 2021). İsveç’te çocuklara ödenen yardım, çocuğun eğitiminin devam etmesi halinde, 20 yaşına kadar uzatılabilmektedir. Genişletilmiş çocuk yardımı adı verilen bu uygulama, 16 - 20 yaş arasındaki çocukların lise eğitimine ya da zorunlu eğitimine devam etmesi halinde ödenmektedir. Bu yardımdan faydalanabilmek için çocuğun ebeveynleriyle beraber yaşaması ve evli olmaması gerekmektedir.

İsveç'te çocuk yardımı uygulamasına benzer bir bakım desteği uygulaması da mevcuttur. Bakım desteği tek bir ebeveyne çocukların yaşaması kaydıyla yapılan ödemelerdir Çocuk öğrenci ise 20, değil ise 18 yaşına kadar bu uygulamadan faydalanılabilir. Ödemeler 15 yaşın altındaki çocuklar için 2018 yılında aylık 1.573 İsveç Kronu olup, 15 yaşından büyük çocuklar için aylık 1.723 İsveç Kronudur. Bakım desteği 2021 yılına kadar devam edecek olup, kademeli olarak azalarak 2021 yılında sona erecek geçici bir uygulamadır (ISSA, 2018: $355)$.

İsveç’te evlat edinmelerde hükümetin bir defaya mahsus toplu bir yardım yaptığı görülmektedir. Evlat edinme yardımı adı verilen bu uygulama için İsveç vatandaşılmayan yabancı uyruklu bir çocuğun evlat edinilmesinde çocuğun 10 yaşından küçük olması gerekmektedir. 2018 yılı için yapılan ödeme miktarı çocuk başına 75.000 İsveç Kronu'dur (ISSA, 2018: 355).

Hasta bir çocuğu bulunan ailede ebeveynler bakım için çalışma hayatının dışında kalıyor ise geçici bir bakım parası ödenmektedir. Çocuk bakım ödeneği, hasta ya da engelli olan çocuğun bakımından kaynaklı gelir kayıplarını telafi etmek amaçlı bir uygulamadır. Bu ödenek $\% 25, \% 50, \% 75$ ve $\% 100$ oranlarında ödenmektedir. 2018 itibariyle ödeme miktarı çocuk başına ayda 2.616 İsveç Kronu - 9.479 İsveç Kronu arasındadır (ISSA, 2018: 355).

Ailelerin barınma masraflarını sübvanse etmek amacıyla ise 18 - 29 yaş arası gençlerin bulunduğu düşük gelirli ailelere yapılan ödemeler de bulunmaktadır. Ödemenin miktarı hane halkı geliri ile konutun yapısına bağlı olarak değişiklik göstermektedir (ISSA, 2018: 355).

\section{III- TÜRKIYYE'DE AIILE ÖDENEKLERİ UYGULAMALARI}

\section{A- Vergi Muafiyetleri}

Sosyal devlet anlayışının temel unsurlarından biri adalettir. Bunu tesis edebilmenin yolu ise adil vergi oranlarından geçmektedir. Adil vergi oranı bireyin geliriyle doğru orantılı birlikte çalışanların en alt seviye yaşam standartlarını etkilemeyecek oranda olabilmesi için vergiden yapılan indirim oranına en az geçim indirimi, başka bir ifade ile asgari geçim indirimi (AGi) denilmektedir (Korkmaz, 2001; Şentürk, 2014). Temel anlamda AGİ, çalışanlar ile eş ve çocuklarının yaşam standartlarını asgari düzeyde koruma amacıyla ücret gelirlerinin bir kısmının gelir vergisinden muaf tutulmasını amaçlamaktadır. Vergiden muaf tutulacak kısım, çalışanların medeni durumuna, eşinin istihdama katılıp katılmadığına ve çocuk sayısına göre belirlenen oranların asgari ücretle çarpımının gelir vergisinin ilk dilimi olan \%15'lik tutarla çarpımı sonucunda bulunmaktadır. Bu oranların eşin çalışmasına ve sahip olunan çocuk sayısına göre farklılık göstermesi, asgari geçim indiriminin ailenin gelirini telafi etme amacını taşıyarak bir nevi aile ödeneği olduğunun işaretidir (Şentürk,2014: 111).

Asgari geçim indiriminden istisnaları hariç olmak üzere Türkiye'de ikamet eden ve çalışması karşılığ 1 ücret elde edenler faydalanabilmektedir. Bu durumda ücret geliri elde etmeyen kişiler asgari geçim indiriminden yararlanamamaktadır. AGİ oranı belirlenmesinde etkili olan çocuk sayısından hareketle, çocuk 18 yaşını; yükseköğrenimine devam ediyorsa 25 yaşını aşmamış olmalıdır. İki ebeveynin de istihdama katıldığı durumda çocuk başına yapılan indirim oranı, ebeveynlerden yalnızca birinin ücretine uygulanmakta, diğer 
ebeveyn ise bekâr yahut eşi çalışan evli oranında AGI'ye sahip olmaktadır (Şentürk, 2016: 112).

\section{B- Çocuk ve Eş Yardımı}

657 sayılı Devlet Memurları Kanunu'nun 4-a maddesi hükümlerine göre kadrolu olarak istihdam edilen memurlar, 4-b maddesi hükümlerine göre sözleşmeli olarak istihdam edilen personel, 4-d maddesi hükümlerine göre istihdam edilen işçilere, aynı kanununun 202, 203, 204, 205, 206. maddeleri kapsamında eş ve çocuk yardımı yapılmaktadır. Kamu toplu sözleşmelerinde, belirlenen esas ve usullere göre verilen bu ödenek, devletin işveren sıfatıyla çalışanlarına tesis ettiği bir ödeme sistemini işaret etmektedir (Atatanır, 2011: 156). Eş yardımına hak kazanabilmek için personelin eşinin ücretli bir işte çalışmıyor olması gerekmektedir. Çocuklar için verilen yardımlar çocukların yaşlarına göre farklılık göstermekte ve 25 yaşına kadar devam etmektedir. Ancak çocukların evlenmesi, gelir vergisine tabi olması ya da ücretli bir işte çalışması durumunda yapılan ödemeler sona ermektedir. İstisnai olarak, 25 yaşın üzerindeki evlenmemiş kız çocuklarının ve herhangi hastalık/engel durumu sebebiyle çalışamayacak durumda olan çocukların varlığı halinde, kamu personeli aile yardımı almaya devam etmektedir. İki eşin de kamu personeli olması halinde çocuk yardımı yalnızca tek ebeveyne yapılmaktadır. 1 Temmuz 2021 ile 12 Aralık 2021 dönemi için belirlenen kamu personeline eş yardımı aylık 409 TL, 6 yaşından küçük her çocuk için aylık 90 TL, 6 yaşından büyük her çocuk için ise aylık 46 TL ödeme yapılmaktadır (BÜMKO, 2021).

\section{C- Doğum Yardımı}

Türkiye'de yeni sayılan bir yardım türü olan doğum yardımı 2015 yılında uygulamaya konulmuştur. 07.04.2015 tarihli Resmî Gazete'de yayımlanan 6637 sayılı Bazı Kanun ve Kanun Hükmün Kararnamelerde Değişiklik Yapılmasına Dair Kanun'un 16. maddesi hükümlerince doğum yardımı Türkiye Cumhuriyeti vatandaşlarına ayrım gözetilmeksizin yapılmaktadır. Bu yardım 15.05.2015 sonrası doğan çocuklar için doğum yapan anneye verilmektedir (Şentürk, 2016: 115). Bu tarihten önce doğan çocuklar için ödeme yapılmazken, sonrasında doğanlar için bir defaya mahsus olmak üzere birinci çocuğa 300 TL, ikinci çocuğa 400 TL, üçüncü ve daha fazla çocuk için çocuk başına 600 TL ödeme yapılmaktadır (Aile ve Sosyal Hizmetler Bakanlığı, 2021). Ancak, çocuk sayısının belirlenmesinde belirtilen tarihten önce doğan çocuklar da hesaba katılmaktadır. Annenin Türkiye Cumhuriyeti vatandaşı olmaması ya da doğum esnasında hayatını kaybetmesi sebebiyle doğum yardımı babaya da yapılabilmektedir. Doğum yardımı, evlat edinilen çocuk için de geçerlidir. Belirtilen tarihten sonra doğan bir çocuğun evlat edinilmesinde, daha önceden çocuk için doğum yardımı ödenmemişse, evlat edinilen aile doğum yardımını alabilmektedir. Ödemeler kendiliğinden değil, başvuru esasına göre yapılabilmektedir Sigortalı olma şartının aranmadığı bu yardımlarda amacın, ailenin korunması ve ekonomik açıdan desteklenmesinin yanı sıra, çocuk sayısı ile doğru orantılı artan yardımsistemi ile genç ve dinamik nüfusun nicel olarak arttırılması olduğunu söylemek mümkündür.

\section{D- Muhtaçlık Esasına Göre Yapılan Aile ödenekleri: Şartlı Sosyal Yardımlar}

Ailenin refahını olumsuz olarak etkileyen en önemli etmen yoksulluktur. Bu nedenle gelişmiş ülkeler yoksullukla mücadelede ailenin birliğini ve refahını arttırmayı hedeflerken, korunan aile yapısının sağlıklı toplumları oluşturacağı gerçeği doğrultusunda hareket etmektedir. Mücadelede en çok tercih edilen yollardan birisi de aile içerisindeki bireylerin beşerî sermaye artırımlarını sağlamak ve bunu sağlayacak maddi imkânları sunmaktır. Aksi takdirde, yoksulluğun daha da katlanarak büyük bir problem haline geleceği yapılan araştırmalarla ortaya konulmaktadır (Atatanır, 2011; Altay, 2005). Şartlı sosyal yardımlar, Dünya 
Bankasının Sosyal Riski Azaltma Projesi Kapsamında uygulanan sosyal yardım programlarıdır (Taşçı, 2010: 60). Türkiye 2001 yılında Dünya Bankası ile imzaladığı ikraz anlaşmasıyla şartlı nakit transferi programı ile tanışmıştır. Programın en temel amacı sosyal risklerin azaltılması kapsamında ekonomik krizlerden toplumun en fazla etkilenen yoksul kesimine ivedi olarak gelir desteği sağlamaktır. Genel anlamda ise bu programın faydası, toplumdaki yoksul kesimin ek gelir elde etmesinin sağlanması, yine bu yoksul kesimin temel sağlık ve eğitim ihtiyaçlarının giderilebilmesi amacıyla sosyal yardım sağlanmasıdır (Fırat, 2013: 190). Şartlı nakit transferleri Türkiye'de, şartlı gebelik yardımı, şartlı sağlık yardımı ve şartlı eğitim yardımı olmak üzere üç şekilde uygulanmaktadır.

Şartlı sosyal yardımlar, sosyal güvencesi olmayan ve 3294 sayılı Sosyal Yardımlaşma ve Dayanışmayı Teşvik Kanunu kapsamında muhtaç ${ }^{4}$ durumunda bulunan ailelere yapılmaktadır. Şartlı gebelik yardımı, muhtaç durumdaki anne adaylarının hamilelik süresince sağlık kontrolüne gitmeleri ve doğumlarını hastanede yapmaları şartıyla yapılan yardımlarken, şartlı sağlık yardımı doğumdan sonra devreye girmekte 0-6 yaş arasındaki çocukların düzenli doktor kontrolüne götürülmesi kaydıyla verilmektedir. Bu kapsamda yapılan yardımların miktarı, gebelik döneminde aylık $45 \mathrm{TL}$, çocuk için aylık $45 \mathrm{TL}$, doğumun hastanede yapılması halinde bir defaya mahsus $100 \mathrm{TL}$, şartlı lohusalık için ise doğumu takip eden ilk 2 ay süresince aylık 45 TL'dir (Aile ve Sosyal Hizmetler Bakanlığı, 2021). Şartlı eğitim yardımları ise ilk ve orta öğretim çağında çocuğu bulunan muhtaç durumdaki ailelerin çocuklarının örgün eğitime devam etmeleri ve okulun açık olduğu aylarda bir ay içerisinde 4 günden fazla devamsızlık yapmamaları şartıyla yapılan yardımlardır. Şartlı eğitim yardımında en önemli kıstas çocuğun eğitimine devam etmesidir. Şartlı eğitim yardımının miktarı, ilköğretime devam eden erkek çocuk için aylık 45 TL, kız çocuk için aylık 50 TL'dir. Ortaöğretime devam eden erkek çocuk için aylık 55 TL, kız çocuk için ise aylık 75 TL ödeme yapılmaktadır (Aile ve Sosyal Hizmetler Bakanlığı, 2021). Görüldüğü gibi yapılan yardımların miktarı çocukların eğitim düzeyine ve cinsiyetine göre farklılaşmakta; ortaöğretime devam eden çocuklara ilköğretime devam edenlere göre; kız çocuklarına ise erkek çocuklara göre daha fazla ödeme yapılmaktadır.

\section{IV- TÜRKIYYE'DE AİLE ÖDENEKLERİ UYGULAMALARINA DAİR ALAN ARAŞTIRMASI}

Bu çalışmanın temel amacı, Türkiye'de ailelere yönelik maddi desteklerden faydalanma, bu destekler konusunda bilgi sahibi olma ve bunlara bakış açısı noktasında ihtiyaçların, beklentilerin ve yardım taleplerinin tespit edilebilmesi ve belirlenen ihtiyaçlar doğrultusunda Türkiye için bir model önerisi oluşturulabilmektir. Bu amaçtan hareketle, çocuk sahibi olan çalışanların, hali hazırda almış oldukları aile ve çocuk ödenekleri konusunda ne düzeyde bilgi sahibi oldukları, alınan ödeneklerin yeterliliği ile aile ve çocuk destekleri konusunda nasıl bir uygulama talep ettikleri ve bu uygulamanın finansmankaynağı konusundaki görüşleri açıklığa kavuşturulmak istenmiştir. Araştırma, 2019 Şubat ve Mayıs ayları arasında Ankara il merkezinde 12'si özel, 23'ü kamu çalışanı olmak üzere toplam 35 kişi ile derinlemesine görüşme tekniği kullanılarak gerçekleştirilmiştir. Araştırmanın analiz birimi çocuk sahibi olan kamu ve özel sektör çalışanlarıdır.

Araştırmaya toplam 20 kadın, 15 erkek katılmıştır. Katılanların yaş grubu 29 ile 55 yaş arasında değişmektedir. Katılımcıların 32'si evli yalnızca 3'ü bekârdır. Evli olanların 6'sının eşi çalışmamaktadır. Bekâr olanlar ise hayatta olan eski eşlerinden çocuk için yardım

\footnotetext{
${ }^{4} 2022$ sayılı kanuna göre muhtaç kişiler, hanede kişi başına düşen ortalama aylık geliri, asgari ücretin net aylık tutarının 1/3'ünden az olduğu Sosyal Yardımlaşma ve Dayanışma Vakıfları tarafından belirlenen kişiler olarak tanımlanmıştır (https://www.mevzuat.gov.tr/mevzuat?MevzuatNo=17049\&MevzuatTur=7\&MevzuatTertip=5) 
almamaktadır. Katılımcıların 22'sinin tek çocuğu bulunurken, 11'inin 2 çocuğu bulunmaktadır. 3 ve 4 çocuğu bulunan yalnızca birer görüşmeci mevcuttur. 2 görüşmeci hariç diğer tüm görüşmecilerin çocukları 18 yaşından küçüktür. Kamu sektöründe çalışan katılımcıların aylık kazancı ortalama $3.900 \mathrm{TL}$ iken, özel sektör çalışanlarının aylık kazancı ortalama 4.800 TL'dir.

\section{V- ARAŞTIRMA BULGULARI}

\section{A- Aile Ödenekleri Bilinci ve Aileye Yapılan Desteklerin Yeterliliği}

Çalışmada, katılımcılara devletten veya işverenlerinden herhangi aile desteği yahut çocuk yardımı alıp almadıkları; alıyor ise bu desteğin miktarı ve yeterli olup olmadığısorulmuştur. $\mathrm{Bu}$ kapsamda özel sektörde çalışanların cevapları, asgari geçim indirimi konusunda bireylerin farkındalığı olmadığını ve asgari geçim indirimini bir aile ödeneği olarak görmediklerini göstermektedir. Özel sektörde çalışan 12 katılımcı böyle bir destek almadığını beyan etmiş, asgari geçim indirimini ancak hatırlatıldığı vakit anımsayabilmişlerdir. Kalanlar ise işveren ile yaptıkları iş akdinde anlaştıkları toplam ücret dışında herhangi bir ek ödeme almadıklarını beyan etmişlerdir. Kamu personeline yönelik "aile yardımı" adı altında doğrudan yapılan desteklerin varlığı ve bu yardımlardan yararlanmak için aile yardımı bildirim formlarının doldurulması zorunluluğu, kamu çalışanlarının bu yardımlara ilişkin bilgisini güncel tutmaktadır. Ancak görüşülen kamu personelinin tamamı aldıkları miktarı belirterek bu miktarın yetersiz olduğunu dile getirmişlerdir.

“... evet, alıyorum. Verilen miktar kesinlikle çok çok az. Çünkü verilenle çocuklarımın hiçbir ihtiyacını karşılayamıyorum, neyine yetecek verdiği o kadar para...” (J-5)

"Ben memur olarak çalışıyorum bu yüzden benim işverenim zaten devlet... Devletin verdiği çocuk yardımını alıyorum ama verilen bu yardım komik denecek kadar az..." (J-11)

"Evet allyorum, 60 TL civarı bir şey ödeniyor. Kesinlikle yeterli değil.Hatta bu parayı vermeseler daha mutlu olurum. Böyle gülünç bir ödeme yapıyor, sonra benim çocuğuma devlet bakmış oluyor. Böyle bir dünya yok.”(J-17)

"97 TL falan allyorum ben. Yetersiz ama bu... Bence şöyle bir şey olmall, çocuk ilkokulu bitirene kadar ayllk 100 TL verilmeli ailesine... Ortaokuldaysa lisedeyse 200 TL verilmeli, yüksekögrenime geçtiyse 300 TL verilmeli... Tabi 2019 yılı için bu rakamları düşünüyorum. Zamanla artmalı bu” (J-4)

\section{B- Aile Ödenekleri Talepleri}

Çalışmada katılımcılara, Devletten ne tür aile ve çocuk desteği talep ettikleri sorulmuş, tamamı Devlet desteklerinin öneminden ve sürekli olması gerektiğinden bahsetmiştir. Katılımcıların içinde bulunduğu koşullar, talep edilen desteğin niteliğini ziyadesiyle belirlemektedir. Bu anlamda, çocuk sahibi olan katılımcılar, büyük ölçüde kreş ve çocuk bakım desteklerini dile getirmişlerdir.

“...evet, yardım olmalı... Bence çocuk 4 yaşına gelene kadar ya da ilkokul da olabilir... Annesi bakmalı bu sürede... Anne yarım gün de çalışabilir ama para almall... Tam maaş almall yani ... İşyeri kreşi de mutlakaolmalı. ” (J-6)

"Kesinlikle olmall... Çocuk yetiştirmede ve çocuğun bakımında devlet desteği mutlaka olmal, bu dönemde çok zor... Hatta Kuzey Avrupa ülkelerindeki gibi uygulamalar olmalı..." (J-26) 
“...çocuklu ailelere, anne ve baba çalışıyorsa kreş ve anaokulu masraflarının kesinlikle karşılanması lazım...” (J-2)

$\mathrm{Bu}$ durum, katılımcıların önemli bir kısmının çocuk bakımı konusunda sorunyaşadığını, özel kreş ve okulların mali külfetine katlanmanın oldukça zor olduğunugöstermektedir. Bunun yanında, bazı katılımcılar, yalnızca bakım ve eğitim maliyetlerideğil, yanı zamanda çocukların kişisel gelişimi için önemli sayılan bir takım sanatsal vesportif faaliyetlerin de devlet tarafından karşılanması konusunda fikir beyan etmişlerdir.

“...olmall. Çalışan annelere kreş veya bakıcı desteği olmall. Çocuk için yapılan maddi destek çocuk başı 300 TL olmalı ayda. Sportif, kültürel faaliyetlere katılan çocuklara ayrıca bir maddi destek sağlanmalı.” (J-11)

“Kesinlikle olmalı... Ama bu bugün verilen 150 TL gibi küçük bir meblăg olmamall. Ya her çocuk için belirli bir yaşam standardı oluşturulup ona göre ödeme yapılmalı ya da devlet özel ayrımı yapmadan herkese eşit şartlar sağlanmalı... Danstır, dildir, müziktir. Bunlar için aileler ek ödeme yapmamalı. Ya da düşük faizle geri ödemeli kredi de verilebilir.” (J-22)

Yukarıdaki ifadelerden de anlaşılacağı üzere, çocuk ihtiyaçlarının çeşitliliğgi, çocuklara yönelik desteklerin de çeşitlenmesi durumunu ortaya çıkarmaktadır. Özellikle çocukluk dönemi rahatsızlıkları, sağlık harcamalarını arttırmakta ve çocuk sağlığı harcamalarına devlet desteği talebini ortaya çıkarmaktadır. Her ne kadar Türkiye'de 18 yaşına kadar tüm çocuklar Genel Sağlık Sigortası kapsamında olsa da özel hastanelere verilen muayene ücreti ile ilaçlardan alınan katılım bedeli bazı görüşmecilerin çocuk sağlığı harcamalarına Devlet desteği talebini ortaya çıkarmıştır.

"Ben açıkçası kreş yardımı istiyorum. Bunun yanında kırtasiye yardımı da gerekli okula gidenler için. Bir de özel sağlık hizmetlerinde indirim...” (J-13)

"Bence bir çocuk 15 yaşına gelene kadar sağlıktan hiç para alınmamalı ne muayeneden ne ilaçtan... Bu yaştan sonra ebeveyn sigortasindan yararlanmalı. Okul hayatında da giyim ve eğitim yardımı yapılmall.” (J-4)

Yalnızca bakım ve sağlık maliyetlerinin karşılanması değil, aynı zamanda okul çağındaki çocukların giyim ve kırtasiye gibi eğitim maliyetlerinin karşılanması da dile getirilen diğer talepler arasında yer almaktadır. Bununla birlikte, bu taleplerin nasıl karşılanması gerektiğine dair öneriler de bulunmaktadır. Görüşmecilerden biri kaldırılanözel okul teşviklerinin farklı eğitim ihtiyaçlarına kanalize edilmesi gerekliliğinden bahsederken, başka bir görüşmeci ise bunun tam tersi, özel ve kamu okulu ayrımının ortadan kalkmasını, tüm çocuklarının gelir sevileri ne olursa olsun eşit eğitim imkânlarından yararlanması gerektiğini dile getirmiştir.

"Kesinlikle olmalıdır. Eğitim üzerine yardım yapılabilir. Özel okul teşvikleri kaldırllıyor, daha farklı uygulamalarla tekrar teşvik kapsamı oluşturulabilir." $(J-35)$

“Aslında bu özel okul teşvikleridir, yardımdır, sigortadır falan yerine,çocukları şu özel okula gönderme zorunluluğu ortadan kalkmalı. Devlet okullarının eski hale döndürülmesi gerekmekte... Çalışan anne babalar için de kreş yardımı yapılmalı..." (J-19)

Yukarıdaki ifadelerde de görüldüğü üzere görüşmecilerin içinde bulundukları ekonomik ve sosyal koşullar Devletten beklentilerini ve aile ödeneklerine bakış açılarını farklılaştırmaktadır. Evli, eşi çalışmayan ve üç çocuğu bulunan özel sektör çalışanı j-19 ekonomik koşullar nedeniyle çocuklarının diğerleri ile eşit firsatlara ulaşmasını talep 
etmektedir. Bu duruma benzer şekilde, tek ebeveynli ailelerin aile ve çocuk destekleri konusundaki talepleri de çift ebeveynli ailelere göre farklılaşmaktadır. Örneğin, eşinden boşanan ve tek çocuğu bulunan J-16 hem çocuğu ile vakit geçirebileceği hem de hanenindiğer işlerini yetiştirebileceği bir "zaman talebinde" bulunmuş; bu anlamda iş aile yaşamının uyumu için esnek çalışma saati talebini dile getirmiştir.

"Ben çocuğumla daha fazla vakit geçirebilmek istiyorum. Bunun için iş saatlerimin düzenlenmesini istiyorum. Örneğin 6'da çıkıyorum işten ... 2 saat erken çıkabilsem hem evime gider yemek yaparım hem çocuğumu parka götürürüm. Kreşten almaya da vaktim kalır.” (J-16)

\section{C- Aile Ödeneklerinin Finansman Kaynağı}

Çalışmada katılımcılara, olmasını istedikleri uygulamaların hayata geçirilebilmesiiçin gerekli finansman kaynağının ne olması gerektiği sorulmuştur. 35 katılımcıdan 22'si finansman kaynağı olarak devleti tercih ederken, 11'i ise hem devlet hem de işverenin katkı sağlaması gerektiğini savunmuştur. Bu soruyla amaçlanan yalnızca finansman kaynağının belirlenmesi değil, aynı zamanda aile ödenekleri uygulamalarında bireyler açısından hangi modelin daha çok tercih edileceğini ortaya çıkarmaktır. İşverenintamamıyla finanse edeceği bir sistemin çalışmaya bağlı modele; devletin finanse edeceğibir sistemin ise evrensel modele daha yatkın olduğu varsayımıyla hareket edilebilir. Bununla birlikte hem çalışma esasına hem de evrensel modele dayalı karma sistem önerisinde bulunan görüşmeciler de mevcuttur. Buradaki devlet kavramı işveren kavramına karşılık gelmemekte, yardım odaklı ya da evrensel modeldeki devlet rolündenbahsedilmektedir.

"Bence bu yük eşit paylaştırılmalı... Hem devlet hem işveren müştereken katkı yapmall..." (J-12)

"Işsveren ve devlet karşılamall... Ortaklaşa yani... Yük birine binerse finansman ayă̆ zorlanabilir.” (J-26)

Bununla birlikte, Devleti işveren rolüyle tanımlayarak cevap veren katılımcılar da bulunmaktadır.

"Hayat pahalılı̆̆ var, bu yüzden özelde çalışana işveren, kamuda çalışana devlet finansman kaynă̆

"Özeldekiler için işveren, kamudakiler için işveren olmalıdır. Kişi hizmet ettiği kurumdan, işyerinden destek almalıdır.” (J-9)

"Kamuda çalışanların finansmanı devlet, özelde çalışanlarınki devlet + işveren olarak müştereken karşılanmalıdır." (J-4)

Katılımcılardan, finansman kaynağının devlet olması gerektiğini savunanların evrensel modelde bir yardım anlayışına daha yatkın olduğu görülmektedir. Bununla birlikte, mali yükün işverene yüklenmesinin kayıt dışı istihdamı arttıracağı ve istihdama katılımı etkileyeceği, kadın işgücünün tercih edilmeyeceği gibi endişeler de dile getirilmektedir. $\mathrm{Bu}$ anlamda aile ve çocuk yardımlarında Devlet etkinliği, bu yardımların işverenin inisiyatifine bağlı olmadan yapılabilmesi ve sürekliliğinin sağlanması açısından gerekli görülmektedir.

"Büyük bir kısmı devlet tarafindan karşılanmalı... İşverenden tedarik edilecekse de işverene vergi indirimi gibi bir fayda sağlanmalıdır. Çünkü işveren bu ve bu gibi maddi yüklerin altında karşllıksız olarak sokulursa, bu yardımlar amacından sapar. Bir süre sonra da işverenler kadın işçi tercih etmeyeceklerdir." (J-17) 
“Devlet olmalı... Çünkü herkes devlet memuru değil... Özel sektördede adamlar daha sigorta primlerini düşük yatırıp kâr etme derdinde... O yüzden işverenler böyle bir şeyi kabul etmezler. Etse bile bunu çalışanın sırtına yük yapar, bizler için değişen bir şey olmaz diye düşünüyorum." (J-22)

"Devlet olmalıdır. Özel işverenler hiçbir zaman çalışanını istisnalar dışında düşünmezler. Bundan dolayı kreş yardımını devletin yapması uygulanabilirlik açısından en doğrusudur." (J-19)

"Sosyal devletin gerekliliği sebebiyle devlet... İşverenin beş yıl sonra batmayacă̆ını kim bilebilir ama devlet devamlılık teşkil eder." (J-16)

Aileye yapılan desteklerin Devlet tarafından karşılanması gerektiğini dile getiren görüşmecilerin bir kısmı ise bunu "yurttaşlık hakkı ve sosyal devlet anlayışı" ile ilişsilendirmişlerdir. Ayrıca ödenen vergilerin bu tür refah hizmetlerinin finansmanı için kullanılması gerektiğini ifade eden görüşmeciler de bulunmaktadır. Bu anlamda, bu görüşmecilerin ifadelerinin tam anlamıyla evrensel modele uyduğu söylenebilir.

"Finansman kaynăğ kesinlikle devlet olmalıdır. Çünkü her çocuk doğuştan bu ödenekleri hak eder." (J-2)

"Devlet tabi ki de... Sosyal devletler çocukların ihtiyacını karşılayan güçlü devletlerdir." (J-28)

"Devlet olmalıdır. Sosyal devlet anlayışı tam anlamiyla uygulanmalıdır. Ayrıca ödediğimiz vergiler çocuklarımıza harcanmalıdır." (J-27)

Görüşmecilerden bir diğeri ise aile ve çocuk desteklerinin işveren tarafindan sağlanması gerektiğini savunmuş; bu durumu işe aidiyetin ve işverene sadakatin bir aracı olarak ifade etmiştir. Ancak bu görüşmecinin kamu çalışanı olduğu düşünüldüğünde, aslında işveren olarak yine devleti kastettiği ifade edilebilir.

"İ̧sveren olmalıdır bu sistemin finansman kaynă̆l. Aidiyet duygusu çok önemlidir. Çalışanın kendini oraya ait hissetmesi gerek. İsveren ne kadar çalışanı sahiplenirse, çalışan oraya aidiyet duyar." (J-11)

Görüşmecilerden yalnızca biri ise ne devletin ne de işverenin bu tür desteklerden sorumlu tutulması gerektiğini; herkesin kendi ihtiyacını yine kendisinin temin etmesi gerektiğini ifade etmiştir. Bu görüşmecinin, çift gelirli bir haneye sahip olduğu ve bakımaihtiyacı olmayan tek bir çocuğunun bulunduğu dikkate alındığında, bakım ve korunma desteğine ihtiyaç duymamasının böyle bir tercihte bulunmasında etkili olabileceği düşünülmektedir.

"Finansman kaynă̆ etmelidir. Zaten devlet çocuklara sağlık sigortası yapıyor, daha ne yapsın? BES uygulamasi olabilir." (J-1)

\section{VI- TÜRKIYY İÇİN AIILE ÖDENEKLERİ MODEL ÖNERISİ}

Türkiye için bir aile ödeneği sistemi önerilirken incelenen ülkelerden ve alan araştırmasında elde edilen bulgulardan hareket edilmiştir. Böylelikle, tasarlanan modeller için hâlihazırda uygulanan şartlı yardımların işleyiş̧lerinin olduğu gibi devam etmesi; asgari geçim indiriminin yenilenerek her çalışan için \%50 oranında uygulanması; kamu personeli aile yardımı, doğum yardımı ve dar kapsamlı diğer aile yardımı uygulamalarının tamamen kaldırılması düşünülmüştür. İncelenen ülkelerin genelinde, çocuk parası adı altında çocukların bakımı ve korunmasına yönelik sistemsel ödemelerin varlığ 1 gözlemlenmiştir. $\mathrm{Bu}$ sebeple, Türkiye için de sistemli ödemelerin var olduğu bir aile ödeneğine ihtiyaç vardır. 
Alan araştırmasından elde edilen bulgulara göre, çocuk yetiştirilmesinde ve bakımında karşılaşılan zorluklardan hareketle çocuklarının eğitimi ve yetiştirilmesi için ayrıca bir aile yardımı modeline ihtiyaç duyulduğu anlaşılmaktadır. Önerilen modelde, her iki ihtiyaca yönelik olarak, "Çocuk Parası" adı altında evrensel bir çocuk bakım desteği ile "Bakım ve Beşerî Gelişim Desteği” adında ailelerin gelir durumları gözetilerek uygulanacak ve yine çocukların desteklenmesini hedef alan bir aile yardımı modelinin varlığı düşünülmüştür.

\section{A- Çocuk Parası Uygulaması}

Tasarlanan "Çocuk Parası" uygulaması, kapsam açısından Evrensel modele, finansman açısından ise sosyal sigorta ve evrensel modelin bileşimine uygundur. $\mathrm{Bu}$ model için, Almanya ve Fransa' daki uygulamalardan esinlenilmiştir (ISSA, 2018). Bu model, tıpkı Genel Sağlık Sigortasında olduğu gibi kapsam bakımından Türkiye Cumhuriyeti'nde bulunan 0-18 yaş arası tüm çocukları kapsamaktadır. Bu noktada herhangi bir gelir testi uygulamasına ihtiyaç duyulmamakta ve ödemeler gelir düzeyine göre değişmemektedir. Tasarlanan programda, ödemeler 18 yaş altında çocuğu bulunan ailelere yapılacaktır. Çocukların vefatı, evlenme ya da sigortalı bir işte çalışması durumunda ödemelerin kesilmesi planlanmaktadır. Ancak modelin kapsamının oldukça geniş olması sebebi ile finansmanının hem işveren prim katkılarına hem de Devlet sübvansiyonlarına dayanması planlanmaktadır. Bu anlamda modelin "aile ödenekleri sigortası" olarak primli rejim kapsamında oluşturulması, Devletin genel sağlık sigortasında olduğu gibi bu sigorta koluna da doğrudan kaynak aktarması düşünülmektedir. Uygulamanın kurumsal tarafının ise Çalışma ve Sosyal Güvenlik Bakanlığg bünyesinde oluşturulacak Aile Sigortası Genel Müdürlüğü tarafından yürütülmesi önerilmektedir. Aile Sigortası Fonunun kurulması, fonun işletiminin ise belirtilen Genel Müdürlük bünyesinde oluşturulacak bir Fon Yönetimi Daire Başkanlığına verilmesiyle daha işler hale geleceği tahmin edilmektedir.

Sistemin finansmanında dikkate alınan varsayımlar şunlardır:

• 2021 yılı TÜİK verilerine göre istihdam edilenlerin sayısı göz önünde bulundurulmuş ve kayıt dışı istihdam göz ardı edilmiştir.

- Modelin işverene getireceği yükün istihdamı etkilemeyeceği varsayımıyla hareket edilmiştir

- 15 - 18 yaş arası istihdama katılan çocuk sayısı ile devlet korumasına alınan çocuk sayısı sifir olarak kabul edilmiştir.

- Hesaplama 2020 yılı sonu çocuk sayısına göre yapılmıştır.

- Tüm çalışanların asgari ücret aldığı varsayımıyla hareket edilmiştir.

Eurostat verilerine göre, 2021 y1lında asgari ücret Fransa'da aylık 1.554 ve Almanya'da ise 1.585 Euro'dur ${ }^{5}$. Fransa' da çocuk parası miktarları gelire göre değişkenlik göstermektedir ancak ortalama olarak asgari ücretin $1 / 7$ 'si ile $1 / 10$ 'u arasında olduğu anlaşılmaktadır. Almanya için ise bu tutar ortalama 200 Euro/ay olduğundan, asgari ücretin 1/7'si olduğu görülmektedir. Şentürk (2016) ise kendi çalışmasında, kreş yardımlarının asgari ücretin $1 / 10$ 'u miktarında olması gerektiğini vurgulamıştır. Türkiye'de 2021 y1lı için brüt asgari ücret tutarı aylık 3.577 Türk Lirasıdır. Türkiye'de çocuk nüfusun ve planlanan sigorta modelinin kapsamının epeyce geniş olması sebebiyle, Türkiye çocuk parası uygulamasının aylık tutarı brüt asgari ücretin $1 / 15^{\prime}$ 'i olarak düşünülmüştür. Bu noktada diğer ülkelerden ayrılan noktası ise, mali külfetinin yoğun olmaması amacıyla, çocuk parası uygulamasına bağlı ödeme yapılan yıldan bir önceki yılın brüt asgari ücretinin temel alınmasıdır. Örneğin,

\footnotetext{
${ }^{5}$ https://ec.europa.eu/eurostat/databrowser/view/earn_mw_cur/default/table?lang=en
} 
2022 yılında uygulamaya koyulacak çocuk parası uygulaması için çocuk başına ödenecek miktar, 2021 y1lı brüt asgari ücret tutarının 1/15'i olan 238,46 Türk lirası/aylıktır.

Türkiye'de 2020 yılı sonunda 0 - 17 yaş arası çocuk nüfus (17 yaş dâhil) 22.750.657'dir (TÜİK, 2021). Her çocuk başına yapılan ödemenin 238,46 Türk lirası olduğu düşünüldüğünde aylık maliyet 5.425.121.668,22 Türk lirası olacaktır.

Pek çok ülkede aile sigortası fonuna katkı sağlayan taraflardan biri işverenlerdir. Şentürk'ün (2016: 134) aile sigortası işveren katkı miktarları hesaplamalarında öngörülen tutar brüt ücretin \%2,87 / \%2,64 / \%2,38 şeklindedir. Buradan yola çıkarak planlanan çocuk parası için her işverenin fona aktarması gereken oranın çalışan başına brüt asgari ücretinin $\% 2,5$ oranında olması öngörülmüştür. 2021 yılı brüt asgari ücret üzerinden hesaplama yapıldığında işverenin her çalışanı için fona aktarması gereken tutar başına maliyeti 89,425 Türk lirası olmaktadır. 2021 yılı Ocak ayı verilerine göre Türkiye'de istihdam edilen kişi sayısı 27.706.000 olarak kayıtlara geçmektedir (TÜIK, 2021). Böylelikle, işverenler tarafından Aile Ödenekleri Fonu için aylık 2.477.609.050 Türk lirası tutarında katkı sağlanacaktır.

Elbette, işveren katkıları tek başına mali külfeti karşılamamaktadır. Bu yüzden, sigorta kolunda toplanan prim gelirinin belirli bir oranı kadar Devlet katkısına ihtiyaç vardır. Asgari geçim indiriminin herkes için $\% 50$ oranında belirlenmesinin esas kaynağı da bu noktaya dayanmaktadır. Çocuklar için uygulanmakta olan asgari geçim indirimi oranlarının iptali sayesinde, prime esas tutar üzerinden tesis edilen gelir vergisinin her çalışan için yaklaşık \%24,60 oranındaki tutarı devlet tarafından Aile Ödenekleri Fonuna aktarılmalıdır. Bu hesaba bağlı kalarak en düşük gelir vergisi miktarı matrahın \%15'i oranında alındığında çalışan başına miktar 456,132 Türk lirası/aylık olmaktadır. Devletin Aile Ödeneği Fonuna aktaracağ çalışan başına miktar bu tutarın \%24,60’1 yani 112,20 Türk lirası/aylık olacaktır. Toplamda devletin fon için aktardığı miktar istihdamdaki kişi sayısını dikkate aldığımızda 3.108.613.200 Türk lirası/aylık olacaktır.

Devletin vergi ile sağladığı katkı ile işverenin \%2,5 prim katkı miktarları toplam tutarı ay bazında 5.586.222.250 Türk lirası olmaktadır. Bu miktar, fon için gerekli aylık miktar olan 5.425.121.668,22 Türk lirasının üstündedir. Ayrıca fon için, veri yokluğu sebebiyle hesaplaması güç olan kamu personeli aile yardımı ve çocuklar için değişen oranlı asgari geçim indirimi maliyetleri ile doğum yardımı maliyetlerinin de eklenmesi öngörülmüşür.

$\mathrm{Bu}$ noktada sisteme geçiş ve sistemin işlerliği önemli noktadır. 2022 yılı Ocak ayında ödemelerin başladığı bir senaryoda, 2021 yılı Haziran ayından itibaren işverenlerin çalışan başına \%2,5 oranın prim ile fona katkı sağlamaya başlaması; devletin ise asgari geçim indirimini revize ederek gelir vergileri üzerinden \%24,60 miktarında ödeneği fona aktarmas1 ile Aile Sigortası Fonunda 6 ay birikim yapılacaktır. Böyle bir birikim, fona hiç katkı sağlanamaması durumunda yaklaşık 3 ay boyunca ödemelerin yapılabilmesini sağlayacaktır. Finansman sistemini rahatlatmak ve gelir dağılımında adaleti sağlamak adına, her ne kadar modelin kapsamı evrensel olsa da üst gelir gruplarının kapsam dışı bırakılması hem sürekliliği destekleyecek hem de alt gelir grupları için rahat erişilebilirlik noktasında destek sağlayacaktır. Bu kapsamda, tasarlanan bu model için aylık brüt asgari ücretin 50 katı tutarını aşan hanehalkı geliri mevzu bahis olduğunda çocuk parasının kesilmesi öngörülmektedir.

\section{B- Bakım Desteği ve Beşerî Gelişim Desteği ile Ücretsiz Ulaşım İmkânı}

Bakım ve Beşerî Gelişim Desteği aile yardımı uygulaması olarak tasarlanmış olup iki kısım halinde incelenmelidir. Primsiz rejim kapsamında tasarlanan bu modelin Finansman kaynağı tamamen devlettir. 2019-2020 eğitim öğretim yılı itibariyle kaldırılan özel okul teşvik 
tutarlarının bu uygulamaya aktarılması planlanmaktadır. Teşvik tutarı yalnızca 2018 yılında 355.000 öğrenci için 1.500.000.000 Türk lirasıdır (BÜMKO, 2019).

Bakım desteğinden 0-6 yaş arasında çocuğu bulunan tek ebeveynli ailelerin ya da her iki ebeveynin de istihdama katıldığı hanelerin yararlanması öngörülmüştür. Bakım desteği kapsamında yapılacak ödemelerin hanelerin gelir durumları baz alınarak muhtaçlık tespiti yoluyla senede iki defa toplu olarak yapılması planlanmaktadır. Beşerî gelişim desteği ise 618 yaş arasında çocuğu bulunan muhtaç ailelere yapılması planlanan yardımı ifade etmektedir. Burada amaç çocuğun okul eğitimi dışında, sanatsal ve sportif faaliyetlere yönlendirilmesi, farklı kurs ve eğitimlerden faydalanmasının desteklenmesidir. Her iki destek programı için, ödemelerin doğrudan kreş/bakıcı yahut kursa yapılması yoluyla aile yardımlarının doğru kanalize edilmesi sağlanmalıdır. Uygulamanın muhtaçlık kriterini gerekli kılması nedeniyle kurumsal tarafının primsiz rejim kapsamında Aile ve Sosyal Hizmetler Bakanlığı Sosyal Yardımlar Genel Müdürlüğü bünyesinde yürütülmesinin uygun olacağ 1 düşünülmektedir.

Ayrıca, 18 yaşından küçük tüm çocuklar için şehir içi ulaşımın ücretsiz olması, oluşan mali külfetin ise ulaşım araçlarına reklam alınarak ekarte edilmesi, ailenin maddi yükünü azaltacak bir uygulama olarak düşünülmektedir.

\section{SONUC}

Sosyal güvenlik politikaları belirlenirken ailedeki değişimin de dikkate alınması gerekmektedir. Farklı aile yapılarının ihtiyaçlarına duyarlı sosyal güvenlik uygulamaları ailenin refahını ve toplumsal barışı sağlama adına oldukça önemlidir. Aileye yönelik sosyal koruma uygulamalarından en bilineni “aile ödenekleridir”. Genellikle çocuk merkezli sosyal koruma programlarını ihtiva eden bu programların temel amacı, sosyal güvenliğin kapsam boşluklarından biri olan çocukların bakımı ve korunmasını sağlamak, beşerî sermayeye yatırım yapmak ve hane yoksulluğunu azaltmaktır.

Liberal refah rejimi modeline tabii ülkelerde aile ödeneklerinin sosyal yardım ekseninde yapıldığı görülmektedir. Muhtaçlık kıstasının esas alındığı bu uygulamalardan faydalananların sayısı ise oldukça sınırlıdır. Öte yandan muhafazakâr ve sosyal demokrat refah rejimi ülkelerinin genelinde, yalnızca yaş kıstasının ve ikametgâh koşulunun arandığı, geniş kapsamlı uygulamalar bulunmaktadır. Bu uygulamaların önemli bir kısmı çocukları hedef almakta, erken çocukluk dönemi bakımından çocukların eğitim ihtiyaçlarına kadar çeşitli destekler sunulmaktadır. Sunulan desteklerin türü ve miktarı kimi durumlarda hane gelirine ve çocuk sayısına göre değişmektedir. Bazı durumlarda ilave çocuk sayısına göre ödeneklerin miktarı artmakta ya da azalarak kesildiği görülmektedir. Çocukların hasta olması ya da engellilik durumlarına göre ek ödemelerin yapıldığı ülkeler de bulunmaktadır. Dolayısıyla ülkelerin aile ve nüfus politikaları ödenek şeklini ve miktarını etkileyebilmektedir. Aile ödeneklerinin finansmanı bakımından devletin, işveren katkılarının ya da her ikisinin bir arada kullanıldığı finansman kombinasyonlarının varlığ 1 dikkat çekmektedir. Bazı durumlarda finansman kaynağına çalışan katkısını da dâhil eden ülke örnekleri bulunmaktadır. Türkiye'de ise henüz geniş kapsamlı ve düzenli ödemelerden oluşan bir aile ödeneği uygulaması bulunmamaktadır. Var olan uygulamaların bir kısmı yalnızca ücretli ve maaşlıları kapsamakta, yapılan desteklerin miktarı yararlanıcılar açışından yeterli görülmemektedir. Muhtaçlık kriterine bağlı olarak yapılan şartlı sosyal transferlerin ise miktarı temel sağlık ve eğitim ihtiyaçları karşılamaya yetecek ölçüde değildir. Ayrıca yapılan yardım artışlarının ekonomik bir göstergeye bağlı olmaması, çoğu zaman sosyal yardım ödemelerinin enflasyonun gerisinde kalmasına ve artı̧̧ dönemlerinin gecikmesine neden olmaktadır. Alan araştırmasından elde edilen bulgular, özellikle çocuk bakımı ve eğitim destekleri konusundaki talepleri ortaya koymaktadır. 
Türkiye için tasarlanan aile ödenekleri modeli, çocuk parası uygulamasını ihtiva etmektedir. Yapılması öngörülen çocuk parası, kapsam açısından evrensel modelde tasarlanmış, finansman kaynağının ise primler ve devlet katkıları yoluyla desteklenmesi düşünülmüştür. “Aile Ödenekleri Sigortası Fonu” ismiyle kurulacak bir fonda, işveren katkı paylarının toplanması ve devletin bu sigorta koluna belirli oranlarda gelir sağlamasi; böylece fonda toplanan paranın 18 yaş altında çocuğu bulunan haneler için aylık ödemeler şeklinde verilmesi esas alınmıştır. "Bakım ve beşerî destek" uygulaması ise yardım odaklı model çerçevesinde tasarlanmış, kreş-bakıcı giderlerinin yılda iki defa sübvanse edilmesi, çocukların sportif ve sanatsal faaliyetlerinin desteklenmesi amaçlanmıştır. Uygulamadan yararlanma ölçütü olarak gelir testi düşünülmüştür. Tüm bu nakdi yardımların yanı sıra, ayni yardım kapsamında değerlendirilebilecek ve yerel yönetimleri de dâhil edecek ücretsiz şehir içi ulaşım uygulamasının var olması gerekliliği üzerinde durulmuştur. Yapılması öngörülen uygulamaların, ailenin desteklenmesiyle toplumsal barışa katkı sağlayacağı düşünülmektedir.

Tüm bu uygulamaların hayata geçirilmesi durumunda, düzenli ve sistemli ödemeler ile hem ailelerin gelir kayıpları tazmin edilecek hem de beşerî sermaye yatırımları artacaktır. Tasarlanan aile ödeneği modelinin yanı sıra diğer sosyal koruma uygulamalarıyla birlikte, kadınların çalışma yaşamına girmesinin teşvik edilmesi ve özellikle düşük gelirli hanelerde yaşayan çocuklar açısından sanatsal ve sportif açıdan beşeri gelişimlerinin desteklenmesi sağlanacaktır.

\section{Kaynakça}

Aile ve Sosyal Hizmetler Bakanlığı (2021). Sosyal Yardım Programlarımız. [https://www.aile.gov.tr/sygm/programlarimiz/sosyal-yardim-programlarimiz/]. (Erişim: 29 Ekim 2021).

Aslantürk, H. ve Koç, F. (2019). Sosyal Hizmet Lisans Öğrencilerinin Evlat Edinme Yoluyla Kurulmuş Tek Ebeveynli Aileler Hakkındaki Görüş ve Düşünceleri: Kocaeli Üniversitesi Örneği. Toplum ve Sosyal Hizmet. 30(3). 814-842.

Atatanır, H. (2011). Sosyal Güvenlik ve Aile Yardımı Uygulamaları. Çalışma İliş̧kileri Dergisi. 2. 143169.

Berlin. (2021). Kindergeld. [https://www.berlin.de/sen/jugend/familie-und-kinder/finanzielleleistungen/kindergeld/]. (Erişim: 29 Ekim 2021).

BMAS (2018). Özetle Sosyal Güvenlik. [https://www.bmas.de/SharedDocs/Downloads/DE/PDFPublikationen/a985-94soziale-sicherung-gesamt-tuerkisch.pdf?_blob=publicationFile\&v=3]

(Erişim: 01 Ağustos 2020).

BMFSFJ

[https://www.bmfsfj.de/bmfsfj/themen/familie/familienleistungen/elterngeld/elterngeld-undelterngeldplus-73752]. (Erişim: 29 Ekim 2021).

Bradshaw J. ve Finch N. (2002). A Comparison of Child Benefit Packages in 22 Countries. University of York Department for Work and Pensions. 174. 160-190.

BÜMKO (2021). Maaş İstatistikleri. [https://www.hmb.gov.tr/bumko-maas-istatistikleri-verileri]. (Erişim: 29 Ekim 2021).

BÜMKO (2019). Eğitim. [https://www.bumko.gov.tr/TR,8113/egitim.html]. (Erişim: 30 Nisan 2019).
CLEISS
(2021)
Allocation
Forfaitaire.

/regime_france4.html\#allocation-forfaitaire]. (Erişim: 29 Ekim 2021).

Cuyers, P. ve Kiely, G. (2000). The Family Roller-Coaster Ride, Family Observer. 2. 4-12.

Daly, M. ve Clavero, S. (2002). Contemporary Family Policy in Ireland and Europe. Belfast: CFP.

Demir, S. ve Çelebi, Ş. (2017). Tek Ebeveynli Ailelerin Sorunları: Nitel Bir Araştırma. Yalova Sosyal Bilimler Dergisi. 7 (13). 111-128.

EUROSTAT (2021). Monthly Minimum Wages. [https://ec.europa.eu /eurostat/databrowser/ view/earn_mw_cur/ default/table?lang=en]. (Erişim: 25 Kasım 2021). 
Familien Portal (2021). Was ist Elterngeld? [https://familienportal.de/ familienportal/familienleistungen/ elterngeld/faq/was-ist-elterngeld-124628\#]. (Erişim: 29 Ekim 2021).

Feyzioğlu, S. ve Kuşçuoğlu, C. (2011). Tek Ebeveynli Aileler. Aile ve Toplum Dergisi. 26. 97-110.

Fırat M. (2013). Gelişmekte Olan Ülkelerde ve Türkiye'de Yoksulluk. Trakya Üniversitesi Sosyal Bilimler Dergisi. 15 (1).185-206.

Försäkringskassen. (2021). Barnbidrag och Flerbarnstillägg. [https://www.forsakringskassan.se/ privatpers/f oralder/barnbidrag]. (Erişim: 29 Ekim 2021).

Gauthier, A.H. (2002). Family Policies in Industrialized Countries: Is There Convergence?. Population: English Edition. 57-3. 447-474.

Goverment of Canada (2021a). Canada Child Benefit. [https://www.canada.ca/en/revenueagency/services/forms-publications/publications/t4114/canada-child-benefit.html]. (Erişim: 29 Ekim 2021).

Goverment of Canada (2021b). Canada Child Disability Benefit. [https://www.canada.ca/en/revenueagency/services/child-family-benefits/child-disability-benefit.html]. (Erişim: 29 Ekim 2021).

Government of Canada (2018). Child and Family Benefits. [https://www.canada.ca/en/services/taxes/child-and-family-benefits.html]. (Erişim: 28 Aralık 2019).

Gökbayrak, Ş. (2010). Türkiye'de Sosyal Güvenliğin Dönüşümü. Çalışma ve Toplum Dergisi. 2. 141162

Henneck, R. (2003). Family Policy in the US, Japan, Germany, Italy and France: Parental Leave, Child Benefits/Family Allowances, Child Care, Marriage/Cohabitation, and Divorce. A Briefing Paper Prepared for the Council on Contemporary Families. Washington: ERIC Institute of Education Sciens.

ILO (2015). 102 No'lu Sosyal Güvenlik (Asgari Standartlar) Sözleşmesi. [https://www.ilo.org/ankara/conventions-ratified-by-turkey/WCMS_377270/lang--tr/index.htm]. (Erişim: 29 Ekim 2021)

ISSA (2018). Social Security Programs Throughout the World: Europe. [https://www.ssa.gov/ policy/docs/progdesc/ssptw/2018-2019/europe/ssptw18europe.pdf.]. (Erişim: 10 Kasim 2021).

ISSA (2019). Social Security Programs Throughout the World: The Americas. [https://www.ssa.gov/ policy/docs/progdesc/ssptw/2018-2019/americas/ssptw19americas.pdf]. (Erişim: 10 Kasım 2021).

Lewin, T. (1999). Gender and the Development of Welfare Regimes. New York Times.

Lichter, D. (1997). Poverty and Inequality Among Children. Annual Review of Sociology. 23. 120-145.

Minujin A., Delamonica E., Davidzıuk A. ve Gonzalez E. D. (2016). The Definition of Child Poverty: A Discussion of Concepts and Measurements. Environment and Urbanization. 481. 18(2). 481-500.

OECD (2020). Poverty Rate. [https://data.oecd.org/inequality/poverty-rate.htm]. (Erişim: 29 Ekim 2021).

Service-public.fr (2021a). Allocations Destinées Aux Familles. [https://www.servicepublic.fr/particuliers/vosdroits/F2552]. (Erişim: 29 Ekim 2021).

Service-public.fr (2021b). Prestation Partagée D'éducation De L'enfant. [https://www.servicepublic.fr/particuliers/vosdroits/F32485]. (Erişim: 29 Ekim 2021).

Şentürk, F. (2016). Türkiye İçin Bir Aile Sigortası Model Önerisi. Sosyal Güvence Dergisi. 9. 102-139. Taşçı, F. (2010). Sosyal Politikalarda Can Simidi. İstanbul: Nobel Yayınları.

TÜIK (2021). Temel İşgücü Göstergeleri: Ocak 2021. [https://data.tuik.gov.tr/Bulten/Index?p=IsgucuIstatistikleri-Ocak-2021-37486]. (Erişim: 29.11.2021)

TÜİK (2020). İstatistiklerle Çocuk. [file:///C:/Users/Pau/ Desktop/\%C4\%B0statistiklerle $\% 20 \% \mathrm{C} 3 \%$ 87ocuk\%202020\%20Bilgi\%20Dok\%C3\%BCman\%C4\%B1.pdf]. (Erişim: 29.11.2021).

UNICEF (2020). Child Poverty Monitor, [https://ourarchive.otago.ac.nz/ bitstream/handle/10523/10585/

CPM_2020_TECHNICAL\%20REPORT.pdf?sequence=6\&isAllowed=y]. (Erişim: 29 Ekim 2021).

UNICEF (2021). The State Of the World's Children. [https://www.unicef.org/reports/state-of-worldschildren]. (Erişim: 29 Ekim 2021).

Ünlütürk Ulutaş, Ç...(2015). İş ve Aile Yaşamını Uzlaştırma Politikaları: Türkiye'de Yeni Politika Arayışları. Ankara Üniversitesi Siyasal Bilgiler Fakültesi Dergisi. 70. 5- 20. 